\title{
Ethnopolitics Across Central and Eastern Europe in a State of Flux: Time for Updating and Upgrading?
}

\author{
Vassilis Petsinis
}

\begin{abstract}
This chapter illustrates why and how the existing theoretical models in the study of ethnopolitics need to be updated in light of the latest developments and the increasing impact of new catalysts. These are, namely, anti-immigration and the rise of the populist and radical right across Central and Eastern Europe. This chapter hints that the more systematic cooperation between academic experts in nationalism and academic experts in the populist and radical right will enable: (a) the former to assess more accurately the degree to which new variables such as Euroscepticism and anti-immigrant trends can reshape ethnopolitics, both as a living reality and a field of study, across Central and Eastern Europe; (b) the latter to formulate new interpretative models about how (right-wing) populist and Eurosceptic actors embed their agendas inside the pre-existing political cultures of nationalism and particularistic identity and memory politics. This chapter introduces and outlines the ethnosymbolic approach as well as the triadic and quadratic configurations of ethnopolitics. Then, it proceeds into a more empirical assessment of the applicability of these theoretical approaches in a series of case studies during the 1990s, as well as the more recent emergence of new catalysts and the ensuing necessity to update and upgrade the existing theoretical models.
\end{abstract}

Keywords Ethnopolitics - Nationalism - Far right - Central and Eastern Europe

This piece has been authored courtesy of an individual research fellowship, as part of the Marie Skłodowska-Curie actions (Horizon 2020 - project name: 749400-MERWBKBS).

\footnotetext{
V. Petsinis ( $\square)$

Johan Skytte Institute of Political Studies, University of Tartu, Tartu, Estonia

e-mail: vasileios.petsinis@ut.ee 


\section{Introduction}

Whereas biopolitics centre on people and geopolitics concentrate on territories, ethnopolitics appear to occupy the intermediate space. If only schematically, one might argue that ethnopolitics interlink groups of people, who are bounded together by an agglomerate of sociocultural affinities through time (the ethnos/ethnie), with specific territories. This explains the interdisciplinarity of ethnopolitics. This field of study has incorporated theoretical and methodological approaches from modern history, political science, as well as sociology and cultural studies. In light of this high diversity and limited space, this section casts its focus on two ostensibly divergent, yet mutually complementary, models in the study of ethnopolitics: the ethnosymbolic approach (Connor 1993; Smith 1999, 2000, 2007) and selected approaches to ethnopolitics beyond groups and groupism (Brubaker 1995, 2002).

The 1990s witnessed the either contested (e.g. Yugoslavia) or negotiated (e.g. Czechoslovakia and the Soviet Union) dissolutions of federal states across Central and Eastern Europe. This process culminated with the emergence of a string of controversies over territorial integrity, state sovereignty, self-determination and minority rights throughout this macro-region. Soon, these groundbreaking developments captivated the interest of academic experts in ethnopolitics all over the globe. A series of specialists formulated their theoretical models for the study of nationalism and ethnopolitics on the basis of empirical material drawn from case studies in this particular macro-region. Therefore, special attention in this chapter is paid to the contemporary state of affairs in ethnopolitics along the Baltic Sea and the Black Sea, including complementary references to other parts of Central and Eastern Europe (e.g. the former Yugoslavia and the Visegrad Four states) were deemed appropriate.

The major objective here is to illustrate why and how the existing theoretical models in ethnopolitics need to be updated in light of the latest developments and the increasing impact of new catalysts (namely anti-immigration and the rise of the populist and radical right) across Central and Eastern Europe. This chapter also hints that the more systematic cooperation between academic experts in nationalism and academic experts in the populist and radical right will enable: (a) the former to assess more accurately the degree to which new variables such as Euroscepticism and anti-immigrant trends can reshape ethnopolitics, both as a living reality and a field of study, across Central and Eastern Europe; (b) the latter to formulate new interpretative models about how (right-wing) populist and Eurosceptic actors embed their agendas inside the pre-existing political cultures of nationalism and particularistic identity and memory politics.

The systemization of this interdisciplinary cooperation can be beneficial to the study of ethnopolitics, nationalism and the populist and radical right not solely in the Baltic States, or the Visegrad Four, but also in Western Europe. In the beginning, this chapter introduces and outlines the ethnosymbolic approach as well as the triadic and quadratic configurations of ethnopolitics. Then, it proceeds into a more empirical assessment of the applicability of these theoretical approaches in a series of case studies during the 1990s; as well as the more recent emergence of new catalysts and the ensuing necessity to update and upgrade the existing theoretical models. 


\section{The Ethnosymbolic Approach: The Nation as a Socio-psychological Phenomenon}

The ethnosymbolic approach largely conceptualizes the modern nation as a sociopsychological phenomenon. According to Anthony D. Smith, the modern nation can be summarized as: 'a named human population, sharing a historic territory, common myths and historic memories, a mass public culture, a common economy and common legal rights and duties for all its members' (Smith 1999: 11) The ethnos can be defined as: 'a named human population with myths of common ancestry, shared historic memories and one or more common elements of culture, including an association with a homeland and some degree of solidarity, at least among the elites' (Ibid: 13). In this light, the nation is a broader notion than the ethnos in that it addresses larger, more diverse and, primarily, political/civic communities. Meanwhile, ethnonationalism, as an ideological current, largely casts its focus on myths of common ancestry and the symbolism built around them; in other words, the more socio-psychological components of nationhood.

In regard to the myths of common ancestry, perhaps the most powerful ones are those referring to the linear continuity of the group through the ages and also those pointing towards an older 'golden age' of the group. These myths acquire a poetic and mystical dimension when associated with an ancestral or 'sacred territory' (e.g. the focal locus of Kosovo and its symbolism in Serbian nationalism), hence the importance attached to 'sacred territories' in all types of nationalist imagery. 'Sacred territories' are endowed with a poetic dimension: these are the territories where the group flourished during its golden age and which have to be defended by all means and at any cost.

The ultimate objective of constituent myths of origin is to create an overriding commitment and bond for the group. Such myths aim to forge an imagined continuity of the group through the ages. Roughly speaking, there exist two types of myths of origin: myths that point towards genealogical descent ('biological continuity' myths) and myths that cite an ancestry of a cultural-ideological variant. 'Biological' myths generate high levels of communal solidarity, since they regard the national community as a network consisting of interrelated kin groups descending from a common ancestor. In this case, imagined blood ties provide the basis for a strictly primordialist sense of belonging and identity (e.g. certain currents of Basque nationalism during the late nineteenth and the early twentieth century).

The other, and perhaps the most common, type of constituent myths of origin are those that rest on the cultural affinity with the presumed ancestors. In this case, we have to do with a spiritual type of kinship, which seeks to trace a 'historical' link between the present ideals and aspirations of the group and those of its presumed ancestors. Cultural-ideological myths of descent stress the persistence of certain types of collective virtue (e.g. the 'heroic spirit') or other distinctive cultural qualities such as language, religion and customs through the ages. They also seek to draw a parallel between these old qualities and the present virtues and cultural qualities of the group in question. 
By locating the present inside the context of the past of the group, constituent myths of origin interpret social changes and collective aspirations in a way that satisfies the drive for meaning, by making up new identities that also seem to be very old. All myths of group descent have as focal point of reference an older 'golden age'. Some examples of such 'golden ages' are, respectively, Periclean Athens in Modern Greek nationalism and the mediaeval Nemanjid dynasty in Serbian nationalism. The reference to a 'golden age' is always linked with a 'myth of decline'. The latter seeks to provide an explanation about how the community fell from its state of prosperity in the past, to its present state of alleged decay. ${ }^{1}$ On such occasions, the 'golden age' serves as a model for the regeneration of the community. ${ }^{2}$

To sum up, then, in Anthony D. Smith's words (Smith 2000: 82-83), constituent myths of origin serve the following purposes:

1. They link past to present (or future) and act as models;

2. They possess external references of comparison, even implicitly;

3. They designate a space and time for action, a territorial program;

4. They contain impulses for collective action, mobilizing people;

5. They are developmental, assuming the possibility of change;

6. They are partly voluntaristic, in that successive generations may add to the heritage and even regenerate themselves.

Such core myths persist and are espoused through state rituals, even in states with a pronounced 'civic' character (e.g. United Kingdom and the United States) (Mach 1989: 101-110). ${ }^{3}$ As far as their mobilizing power is concerned, this has mainly to do with the fact that these myths pertain to the non-rational domain of the 'nation'. Constituent myths of origin endow the nation with a near universality through the employment of selected images and phrases (e.g. home, forefathers, brothers and mother) that aim at forging a subconscious bond of integrity among its members. This is of vital importance for mass mobilization since, as Walker Connor phrases it, 'people do not voluntarily die for things that are rational' (Connor 1993: 206). Even Marxists-Leninists have taken advantage of the mobilizing potential of constituent myths of origin, despite the philosophical incompatibility between nationalism and Communism (Ibid: 199). ${ }^{4}$

\footnotetext{
${ }^{1}$ For instance, nineteenth century Greek intellectuals (Adamantios Koraes, in particular) bewailed the degeneration of their contemporary Greeks in comparison to the underlying genius of their community, as revealed in its purest form during the golden age of Periclean Athens (fifth century BC).

${ }^{2}$ On some occasions, the need for the regeneration of the community may acquire rather mystical and semi-religious dimensions. A notable example is the notion of the 'Serbian Golgotha' in Serbian nationalist imagery. On this issue, see Tomašić (1948: 30).

${ }^{3}$ An appropriate example of this kind is certain British state rituals (e.g. Remembrance Day).

${ }^{4}$ For example, Mao Tse-tung frequently stressed the 'family ties' among the Chinese people, and their descent from a common ancestor (Huang-ti, the legendary first emperor of China).
} 
The academic value of the ethnosymbolic approach consists in that it seeks to situate the position of constituent myths of origin inside modern nations. This, in turn, helps set in context how the political and cultural/socio-psychological components of modern nations may, in practice, overlap with each other.

\section{Between Triadic and Quadratic Configurations of Ethnopolitics}

Rogers Brubaker has coined the concept of groupism. This notion addresses the tendency to view ethnic groups and identities as bounded, regards them as the leading protagonists of conflicts and treats them as the key units of social discourse. Ethnic conflict is obviously the conflict between ethnic groups but these groups should not be perceived as compact entities or 'collective individuals'. In accordance to Brubaker (2002: 163-189), group cohesion should be viewed as a continuous process that in some cases may be brought to completion but in others fail. Within this frame of interpretation, the notion of categories is of pivotal significance. For example, 'Russian', 'Ukrainian' or 'Moldovan' (as ethnic definitions) constitute categories but not groups. In order for these categories to generate a high degree of solidarity among a given number of people, become external markers and, ultimately, culminate into group cohesion (or groupness), a whole process is required.

The engineers of this process are certain actors, most commonly organizations, who claim to speak in the name of an ethnic group. These organizations may range from paramilitary formations and terrorist organizations to political parties and cultural associations. Consequently, the strategies employed by these actors in order to achieve groupness differ considerably from each other. They may range from armed operations to political engagement within mainstream structures. The common denominator, however, remains the endeavour to make good use of the historical background, constituent myths, as well as an array of cultural and socio-psychological catalysts, in order to cement group cohesion (Ibid: 170-173).

Attention should be paid to the cognitive dimension of ethnic conflict. In other words, what is it, specifically, that makes an armed or political conflict an ethnic one? The 'ethnic' quality is not intrinsic to ethnic conflict. It is up to organizations and a variety of individuals (e.g. government officials, political activists, journalists and others) to frame and, ultimately, constitute a conflict as ethnic. Framing an incident as a 'pogrom' or a 'riot' is not just a matter of external interpretation but an act of definition that can have important consequences (Brubaker et al. 2004: 37 and 47). The more an organization succeeds in constituting a conflict as ethnic or interpreting a governmental decision as detrimental to the group that this organization claims to represent, the more it succeeds in forging cohesion within the group. This success acquires a higher significance if the organization manages to internationalize its standpoints. 
Another useful concept, coined by Rogers Brubaker, is the triadic nexus theory (Brubaker 1995: 109). According to the author, nationalism in multiethnic societies is often a dynamic interaction among the 'nationalizing state', the national minority (or minorities) living in that state and the minority's (or the minorities') external national homeland (or kin-state). A 'nationalizing state' is the one which subtly promotes the culture, language and political primacy of the titular nation within the state through the governing institutions. Each of these actors is not a static entity but a 'variably configured and continuously contested political field'. The interaction among these actors depends upon the relations and balances within each of them. Within this framework, the minorities' frequent response to the policies of the 'nationalizing state' is to push for more cultural or territorial autonomy and resist actual or perceived policies of discrimination. The external homeland's role is to monitor the situation of their co-ethnics in the state in question, protest alleged violations of their rights and assert the right, even the obligation, to defend their interests.

The model of ethnic democracy can provide a trajectory for the nationalization of political institutions and the public space. Based on the Israeli precedent, Sammy Smooha defines ethnic democracy as an arrangement which 'combines a structured ethnic dominance with democratic rights for all' (Smooha 2001: 8). Ethnic democracy is 'democracy that contains the institutionalization of dominance of one ethnic group...the "democratic principle" provides equality between all citizens and members of the society while the "ethnic principle" establishes preference and dominance' (Ibid: 24-25). Therefore, although providing the formal representative institutions of liberal democracy, ethnic democracy tends to restrict the participation of certain minority groups in the political processes. Two representative examples of the ethnic democracy model and its implementation in Central and Eastern Europe are the cases of post-Communist Estonia and Latvia.

Rogers Brubaker's theoretical matrix became highly topical inside the background of numerous disputes over the collective statuses of ethnic minorities across Central and Eastern Europe during the 1990s. In light of the increasing significance of international institutions/organizations and supranational processes in Central and Eastern Europe, the prospect of EU membership started functioning as a powerful pole of attraction for most post-Communist states. This enhanced the EU's soft power diplomacy vis-à-vis the candidate states. Soft power refers to the aggregate of the formal, as well as informal, mechanisms that the EU has employed in order to promote the candidate states' compliance with the conditions that it has set to them (Bruszt and Stark 2003; Haughton 2007). This development prompted several academic experts to reformulate Brubaker's triadic nexus into a quadratic one, in light of the EU's eastward enlargement, and add the EU as a fourth actor inside the nexus (Pettai 2006; Smith 2002; Budryte 2005).

Due to its limited space, this chapter has mainly relied upon David Smith's concept of quadratic nexus (Smith 2002, 2003). In the author's own words, 'the role of international organizations should be central to any discussion of post-Communist identity politics in Central and Eastern Europe' (Smith 2002: 9). Slightly amending the terminology used by Brubaker, Smith argues that 
'Europeanization can thus be regarded as a variably configured and continuously contested political field in which different states, organizations, parties, movements or individual political entrepreneurs vie to impose their own particular political agenda' (Ibid: 11). On numerous occasions, the author contends that it was the impact of the EU as a 'fourth pillar' that spurred the transition from 'nationalizing statehoods' to multiple 'integration strategies', since the year 2000, throughout Central and Eastern Europe (Smith 2003).

\section{From the Theory to Practice: The 1990s}

Empirical evidence from a series of conflicts, during the 1990s, testifies to the validity of Rogers Brubaker's outlook on ethnicity as a process (Brubaker 2002). For instance, nowadays, it has become almost customary for academic and non-academic experts to regard the multiple wars of secession within the former Yugoslavia (1990s) primarily as ethnic conflicts. Nevertheless, this occurrence is indissolubly linked to the multifaceted institutionalization of ethnicity (e.g. the peoples/narodi and ethnic minorities or 'nationalities'/narodnosti) inside a multi-level constitutional arrangement (i.e. the republics, autonomous provinces and self-management units) within the former Yugoslavia. These structural realities gradually facilitated the joint endeavour by a multitude of external and internal actors (e.g. political leaderships, paramilitary groupings, political activists and journalists), during the 1990 s, to frame these conflicts as primarily ethnic.

In regard to the triadic nexus theory, Yugoslavia's contested dissolution process (early and mid-1990s) witnessed the endeavour of virulent new leaderships to re-nationalize the state institutions (i.e. Serbia under Slobodan Milošević and Croatia under Franjo Tuđman). This resulted in discriminatory policies vis-à-vis specific minority groups (e.g. ethnic Serbs in Croatia and ethnic Albanians in Serbia) and the ensuing endeavour of their kin states to protest against perceived violations of collective rights. These developments provided Rogers Brubaker with the primary material for the conceptualization of the triadic nexus as a theoretical model for the interpretation of ethnic conflict (Brubaker 1995).

During the same period, the ethnically diverse parts of Romania (namely Transylvania) witnessed the symbolic competition between Romanian and ethnic Hungarian nationalist groupings in the public space (e.g. in urban centres such as Cluj-Napoca) as well as their simultaneous endeavour to generate groupness inside the Romanian majority and the ethnic Hungarian minority. These developments on the grass-roots level, in combination with the occasional interference by Romania's larger political parties as well as a string of Hungarian governments in Budapest, provided Rogers Brubaker with additional raw material towards the further concretization of the triadic nexus theory (Brubaker et al. 2008). Lastly, developments such as the gradual heightening of the controversy between Northern Macedonia and Greece over the cultural heritage of Ancient Macedonia, since the early 1990s, 
hinted at the validity of the ethnosymbolic approach in regard to the socio-psychological appeal of constituent myths and symbols as well as their potential intersection with the realm of foreign policy (Danforth 1997).

\section{From the Theory to Practice: Contemporary Cases}

By contrast, ethnicity never became institutionalized to the same degree within the Soviet Union, whereas this federation never evolved to a highly multi-level arrangement comparable to the former Yugoslavia. Therefore, despite any attempts to ethnicize it, the conflict in Donbas (southeast Ukraine), for instance, is primarily being perceived as a political one through a variety of angles. Moldova provides one more environment where internal cleavages primarily revolve around favourable and non-favourable dispositions vis-à-vis the Kremlin and/or the Euro-Atlantic institutions and not ethnicity per se.

However precarious it might be to regard the ongoing conflict in southeast Ukraine as an ethnic one, Rogers Brubaker's triadic nexus theory remains topical inside this context. On the one hand, the post-Maidan era saw the coordinated project by several political and non-political actors (e.g. journalists and segments of the intelligentsia) in Russia with the objective to mobilize the anti-Maidan cohorts in southeast Ukraine and elsewhere via the utilization of symbols associated with the Great Patriotic War and the Soviet anti-Fascist struggle (1940s). ${ }^{5}$ On the other hand, the post-Maidan realities accelerated the counter-project of the new elites in Kyiv with the aims to: (a) 'de-Sovietize' Ukrainian national identity through the excision of any visible vestiges from the Soviet era (e.g. the removal of remaining monuments); (b) enhance the institutional status of the Ukrainian language in the state administration and bureaucracy.

Moreover, in Russia, the period since 2014 has seen the orchestration of a joint political-intellectual project with the objective to legitimize Crimea's annexation into the Russian Federation. As part of this endeavour, Crimea is portrayed as a territory indissolubly linked with the Russian nation through time, through references to the Crimean War (1853-1856) and other major historical events. ${ }^{6}$ On this occasion, the intersection among constituent myths of origin, ancestral territories and contemporary political objectives - as highlighted by the proponents of the ethnosymbolic approach-becomes clear. The same thing can be argued about the enduring relevance of the ethnosymbolic approach in regard to the 'de-Sovietization' process in post-Maidan Ukraine. In spite of their divergent outlooks on 'groupness' and groupism, the two theoretical models discussed in this

\footnotetext{
${ }^{5}$ This project largely consisted in tentative portrayals of the war in southeast Ukraine as a conflict between 'neo-Fascists' (i.e. the post-Maidan Ukrainian government) and 'anti-Fascists' (i.e. the Donbas separatists). On this issue, see the relevant excerpts of Vladimir Putin's Crimean speech (18 March 2014) at: http://en.kremlin.ru/events/president/news/20603.

${ }^{6}$ Ibid.
} 
chapter converge, if only by default, in that they both set in context how the politicization (or, occasionally, weaponization) of ethnicity operates as a joint socio-psychological and political process within different environments; hence, the persisting relevance and validity of these theoretical approaches also in regard to contemporary cases.

\section{New Actors Enter the Fore: The Populist and Radical Right in Central and Eastern Europe}

Nevertheless, new catalysts have entered the fore and can decisively impact on the study of ethnopolitics across Central and Eastern Europe. In particular, controversies over immigration and the refugee crisis gain increasing significance and they may even occasionally overshadow debates over 'traditional' cleavages with ethnic implications (e.g. disputes over minority rights). On numerous occasions, this largely remains a virtual debate in that the physical presence of war refugees and other Muslim migrants in Central and East European societies is rather limited. Still, this has sufficed for a wide spectrum of, mainstream as well as non-mainstream, political actors to capitalize on the public apprehension over immigration and augment their popularity. A common denominator among all these endeavours has been the utilization of the cultural argumentation against the EU's fixed quotas arrangement for the redistribution of refugees.

For example, in Hungary, nominally centre-right, Prime Minister Viktor Orbán justified his decision to erect a razor wire fence along the southern border (2015) via accusing the European Commission of 'irresponsibility', underlining that 'Europe and European culture are rooted in Christian values' and judging that 'there is no alternative, and we have no option but to defend Hungary's borders'. ' Further to the north, nominally centre-left, Slovakia's Prime Minister, Robert Fico, attempted to draw tentative comparisons between the refugee and the Roma questions arguing that if the social integration of the Slovak Roma has been so complex, the social integration of Muslim migrants would be tantamount to impossible. ${ }^{8}$ In this chapter, however, primary attention is paid to the more coordinated and systematic weaponization of the migration crisis by the populist and radical right.

A series of academic experts on the populist and radical right have highlighted a qualitative difference between the political engagements of populist and radical right-wing parties in Western and Eastern Europe (Allen 2017; Pytlas 2015), whereas within the former context, the primary emphasis is laid on anti-immigrant rhetoric, within the latter context, and ethnic minorities are seen to assume the role

\footnotetext{
${ }^{7}$ https://www.theguardian.com/world/2015/sep/03/migration-crisis-hungary-pm-victor-orbaneurope-response-madness.

${ }^{8}$ https://www.politico.eu/article/migrants-are-central-europes-new-roma-refugees-viktor-orbanrobert-fico/.
} 
of scapegoats. As Lenka Bustikova puts it, 'in the more ethnically pluralistic societies, (populist and radical right-wing) parties seeking electoral support mobilize against constitutive, larger ethnic groups, with a high degree of politicization' (e.g. the cases of Slovakia, Latvia and Croatia) (Bustikova 2018: 566-567). Since the 1990s, this scapegoating has been legitimized through references to the longer historical trajectories and the fears of irredentist tendencies among politicized minority groups.

The same treatises contend that the concretization of the adequate protection of the rights and freedoms of national minorities, as one of the conditions for accepting post-Communist states into the EU (established by the Copenhagen Criteria, 1993), ${ }^{9}$ forged a solid bond among minority rights, democratization and Europeanization (Bustikova 2015: 67). In this light, and to a remarkable extent, the populist and radical right in the more ethnically pluralistic societies of Central and Eastern Europe started building their Eurosceptic platforms on varying allegations that the EU 'imposes' minority rights from the exterior and weakens national sovereignty (i.e. the early and mid-1990s). ${ }^{10}$

Nevertheless, together with ethnonationalism, nativism has recently come to occupy a locus of primary significance in the political engagement of East European populist and radical right-wing parties. With specific regard to immigration and citizenship, this notion holds that primacy must be given to the political rights, the economic needs and the cultural identity of the ethnic/native members of the titular nations (Mudde 2007; Pappas 2018). Therefore, if only schematically, nativism can be designated as a sub-branch of ethnonationalism with a more concrete and pronounced stress on anti-immigration and xenophobia. East European populist and radical right-wing parties have re-appropriated key aspects from the pre-existing political cultures of nationalism in specific countries and embedded them into their agendas on anti-immigration.

For instance, on certain occasions, the anti-refugee and anti-immigration rhetoric of the East European populist and radical right even seems to sideline more 'traditional' areas of discord in domestic ethnopolitics (e.g. the Naše Slovensko/'Our Slovakia' party and its prioritization of the migration crisis over the ethnic Hungarian question in Slovakia) (Kluknavská and Smolik 2016). On other occasions, populist and radical right-wing parties (e.g. the Estonian Conservative People's Party/EKRE and Latvia's National Alliance/NA) tend to interlink the collective memories of 'colonization' under the Soviets (Annus 2012; Peiker 2016) with the collective anxieties of becoming 'colonized' again by others in the future (e.g. refugees and/or other migrants) (Braghiroli and Petsinis 2019; Kasekamp et al. 2018).

\footnotetext{
${ }^{9}$ Presidency Conclusions, Copenhagen European Council (1993, p. 7.A.iii), available online at: http://www.europarl.europa.eu/enlargement/ec/pdf/cop_en.pdf (accessed 10 June 2018). Also, see http://ec.europa.eu/enlargement/enlargement_process/accession_process/criteria/index_en.htm (accessed 10 June 2018).

${ }^{10}$ On the case of Latvia, see: Björkman-Bennich and Johansson (2012), Kelley (2004: 83-84), Jubulis (2001: 128-129).
} 
Furthermore, by contrast to the 1990s and the 2000s, the appeal of EU membership as an additional fourth actor inside Rogers Brubaker's triadic nexus theory seems to be eroding while various brands of Euroscepticism are on the rise. Schematically, Euroscepticism can be defined as the: 'outright and unqualified opposition to the process of European integration' (Taggart 1998: 365-366). In practice, however, Euroscepticism is a multifaceted phenomenon. From a macropolitical perspective, Euroscepticism can become subordinated to pre-existing ideological currents and manifest as either right wing or left wing. Depending on either its firm rejection or more accommodating stance vis-à-vis the process of European integration, it can be hard or soft. In correlation to the prevailing political and socioeconomic circumstances, Euroscepticism can place a greater emphasis on the economy, regional security, immigration and/or cultural identity issues (or multiple combinations of all the above). Lastly, Euroscepticism can manifest in European states inside as well as outside the EU (e.g. Serbia and Ukraine).

Hard Euroscepticism consists in the principled opposition to the EU and either demands the withdrawal of given states from the EU or firmly objects to their prospects of EU membership (Taggart and Szczerbiak 2002: 4; Kopecky and Mudde 2002; Flood and Usherwood 2005). Soft Euroscepticism does not entail the principled opposition to the EU but centres on policy areas where a divergence between the 'national interest' and the EU trajectory is perceived (Taggart and Szczerbiak 2008; Kopecky and Mudde 2002). Meanwhile, two areas of utmost significance for right-wing Eurosceptics across the Continent are: (a) varying degrees of opposition to immigration and insistence on the principle of hard borders; (b) safeguarding national sovereignty from the 'domination of Brussels'.

For instance, in the Baltic States, populist right-wing parties with an increasing appeal and varying shades of, nominally soft, Eurosceptiscism (e.g. EKRE and NA) cast doubts on the extent to which EU membership can upgrade the security status of these states vis-à-vis Russia (i.e. geopolitical Euroscepticism). This is frequently coupled with economic Euroscepticism and the subsequent calls for the taxation of tax-free foreign capital ${ }^{11}$ as well as the objection to the acquisition of Estonian/ Latvian land by foreign nationals. Meanwhile, the sociocultural Euroscepticism of the far right throughout Central and Eastern Europe capitalizes not solely on public opposition to the EU's fixed quotas for refugees but also on fears that the EU promotes the import of 'alien' gender norms to these societies (e.g. the EU guidelines on LGBT rights).

Even though the recent migration waves also constitute an ethnocultural 'Other', this variant of otherness is a brand new one and qualitatively distinct from the earlier instances of tension between national majorities and ('settled') ethnic minorities. Furthermore, the prominent locus of nativism in the agendas of the populist and radical right across Central and Eastern Europe often operates as a catalyst which regulates, or even potentially 'bridges', the cleavages between national majorities and, erstwhile 'unreliable', minority groups (e.g. ethnic

\footnotetext{
${ }^{11}$ EKRE (2015).
} 
Hungarians in Slovakia or ethnic Poles in Lithuania); in light of the mounting apprehension vis-à-vis the new migrants. In addition, the constantly fluctuating and non-territorial scope of the European migration crisis renders the triadic nexus theory irrelevant within this particular context. Lastly, one might contend that, beyond the triadic and quadratic configurations of ethnopolitics, Euroscepticism has been emerging as a virulent fifth actor all over Central and Eastern Europe.

\section{In Lieu of a Conclusion}

As it becomes transparent in this chapter, the existing classification schemes for ethnopolitics need to be updated and upgraded, especially in light of the latest developments across Central and Eastern Europe. By contrast to the older treatises on the populist and radical right in Central and Eastern Europe, and their greater stress on the apprehension of these parties towards ethnic minorities, empirical research demonstrates that several members of this party-family throughout the macro-region have been seeking to augment their popularity along the systemization of anti-immigrant engagement. ${ }^{12}$ In particular, an emerging nexus which appears to be rather commonplace among parties of the populist and radical right in Central and Eastern Europe is the one that consists of: domestic ethnopolitics, regional geopolitics and 'new' identity politics (namely anti-immigration and, to a secondary extent, opposition to LGBT rights). This nexus, in turn, seems to be firmly anchored inside the Eurosceptic and anti-establishment agendas of these parties.

In all of this, it should be borne in mind that the trajectories towards capitalizing on anti-immigration sentiments have been rather idiosyncratic across Europe. Anti-immigration parties and groupings tend to embed their narratives primarily into symbols and imageries derived from their own societies' historical experience. In this light, the cooperation between academic experts in ethnopolitics and academic experts in the populist and radical right needs to become more extensive and systematic. On the one hand, this will enable experts in ethnopolitics to assess more precisely the degree to which new variables such as Euroscepticism and anti-immigrant trends can reshape ethnopolitics, both as a living reality and a field of study, across Central and Eastern Europe.

On the other hand, this systematic cooperation will enable experts in the populist and radical right to formulate new interpretative models about how (right-wing) populist and Eurosceptic actors across this region embed their agendas inside the pre-existing political cultures of nationalism and particularistic identity and memory politics. At a first instance, this will require a greater number of empirical, in-depth,

\footnotetext{
${ }^{12}$ On the Hungarian case and the party of Jobbik (Movement for a Better Hungary), see: Kovarek et al. (2017: 63-87). For the party's official position, see: 'Immigration increases tensions in Europe' (https://www.jobbik.com/immigration_increases_tensions_europe) (accessed 12 June 2018).
} 
studies on the operation of specific political actors within specific countries. Although this chapter is anchored in the political experience of Central and Eastern Europe, as a departure point, this interdisciplinary cooperation can be equally beneficial to the study of ethnopolitics, nationalism and the populist and radical right in Western Europe.

\section{References}

Allen, T. J. (2017). All in the party-family? Comparing far-right voters in Western and post-Communist Europe. Party Politics, 23(3). https://doi.org/10.1177/1354068815593457.

Annus, E. (2012). The problem of Soviet Colonialism in the Baltics. Journal of Baltic Studies, 43 (1), 21-45.

Björkman-Bennich, L., \& Johansson, K. M. (2012). Explaining moderation in nationalism: Divergent trajectories of national conservative parties in Estonia and Latvia. Comparative European Politics (online version). https://doi.org/10.1057/cep.2011.28.

Braghiroli, S., \& Petsinis, V. (2019). Between party-systems and identity-politics: The populist and radical right in Estonia and Latvia. European Politics and Society (online version). https:// doi.org/10.1080/23745118.2019.1569340.

Brubaker, R. (1995). National minorities, nationalizing states and external homelands in the New Europe. Daedalus, 124(2), 107-132.

Brubaker, R. (2002). Ethnicity without groups. Archives Européennes de Sociologie, XLIII(2), 163-189.

Brubaker, R., Loveman, M., \& Stamatov, P. (2004). Ethnicity as cognition. Theory and Society, 33, 31-64.

Brubaker, R., Feischmidt, M., Fox, J., \& Grancea, L. (2008). Nationalist politics and everyday ethnicity in a Transylvanian Town. New Jersey: Princeton University Press.

Bruszt, L., \& Stark, D. (2003). Who counts? Supranational norms and societal needs. East European Politics and Societies, 17(1), 74-82.

Budryte, D. (2005). Taming nationalism? Political community building in the Post-Soviet Baltic States. Aldershot: Ashgate.

Bustikova, L. (2015). The democratization of hostility: Minorities and radical right actors after the fall of Communism. In M. Minkenberg (Ed.), Transforming the transformation. New York: Routledge.

Bustikova, L. (2018). The radical right in Eastern Europe. In J. Rydgren (Ed.), The Oxford handbook of the radical right. Oxford: Oxford University Press.

Connor, W. (1993). Ethnonationalism: A quest for understanding. London: Routledge.

Danforth, L. (1997). The Macedonian conflict: Ethnic nationalism in a transnational world. New Jersey: Princeton University Press.

EKRE. (2015). Riigikogu 2015. https://ekre.ee/riigikogu-2015/. Accessed June 7, 2018.

Flood, C., \& Usherwood, S. (2005). Positions, dispositions, transitions: A model of group alignment on EU Integration. Paper presented at the 55th Annual Conference of the Political Studies Association, University of Leeds, 5-7 April 2005.

Haughton, T. (2007). When does the EU make a difference? Conditionality and the accession process in Central and Eastern Europe. Political Studies Review, 5, 233-246.

Jubulis, M. (2001). Nationalism and Democratic Transition: The Politics of Citizenship and Language in Post-Soviet Latvia. University Press of America.

Kasekamp, A., Madison, M., \& Wierenga, L. (2018, April). Discursive opportunities for the Estonian populist radical right in a digital society. Problems of Post-Communism (online version). https://doi.org/10.1080/10758216.2018.1445973. 
Kelley, J. (2004). Ethnic politics in Europe: The power of norms and incentives. New Jersey: Princeton University Press.

Kluknavská, A., \& Smolik, J. (2016). We hate them all? Issue adaptation of extreme right parties in Slovakia 1993-2016. Communist and Post-Communist Studies, 49(4), 335-344.

Kopecky, P., \& Mudde, C. (2002). The two sides of Euroscepticism: Party positions on European Integration in East Central Europe. European Union Politics, 3(3), 297-326.

Kovarek, D., Róna, B., Hunyadi, B., \& Krekó, P. (2017). Scapegoat-based policy-making in Hungary: Qualitative evidence for how Jobbik and its Mayors govern municipalities. Intersections, 3(3), 63-87.

Mach, Z. (1989). Symbols, conflict and identity. Krakow: Krakow University Press.

Mudde, C. (2007). Populist radical right parties in Europe. Cambridge: Cambridge University Press.

Pappas, T. (2018). How to tell nativists from populists. Journal of Democracy, 29(1), 148-152.

Peiker, P. (2016). Estonian nationalism through the postcolonial lens. Journal of Baltic Studies, 47 (1), 113-132.

Pettai, V. (2006). Explaining ethnic politics in the Baltic States: Reviewing THE Triadic nexus model. Journal of Baltic Studies, 37(1), 124-136.

Pytlas, B. (2015). The populist radical right in Central and Eastern Europe: Ideology, impact, and electoral performance. London \& New York: Routledge.

Smith, A. D. (1999). Myths and memories of the nation. Oxford: Oxford University Press.

Smith, A. D. (2000). The nation in history: Historiographical debates about ethnicity and nationalism. Oxford: Oxford University Press.

Smith, A. D. (2007). Nationalism: Theory, ideology, history. Oxford: Oxford University Press.

Smith, D. (2002). Framing the national question in Central and Eastern Europe: A quadratic nexus? The Global Review of Ethnopolitics, 2(1), 3-16.

Smith, D. (2003). Minority rights, multiculturalism, and EU-enlargement: The case of Estonia. Journal on Ethnopolitics and Minority Issues in Europe, 1, 1-39.

Smooha, S. (2001). The Model of Ethnic Democracy. ECMI Working Papers (\#13, October 2001), European Centre for Minority Issues, Flensburg.

Taggart, P. (1998). A touchstone of dissent: Euroscepticism in contemporary Western European party systems. European Journal of Political Research, 33(3), 363-388.

Taggart, P., \& Szczerbiak, A. (2002). The party politics of Euroscepticism in EU member and candidate states. SEI Working Paper 51.

Taggart, P., \& Szczerbiak, A. (2008). Opposing Europe? The comparative party politics of Euroscepticism. Oxford: Oxford University Press.

Tomašić, D. (1948). Personality and culture in East European politics. New York: George W. Stewart Publisher Inc. 